\title{
CD-MEKC Method to Analyze Triterpene Acids in Traditional Chinese Medicines
}

\author{
Hui Du ${ }^{a, b}$ and Xiaoqing Chen*,a \\ ${ }^{a}$ College of Chemistry and Chemical Engineering, Central South University, Changsha 410083, \\ People's Republic of China \\ ${ }^{b}$ College of Medicine, Xi'an Jiaotong University, Xi'an 710061, People's Republic of China
}

\begin{abstract}
Um método cromatográfico eletrocinético micelar modificado por ciclodextrina (CD-MEKC) foi desenvolvido para separar e determinar ácido betulínico (BA), ácido oleanólico (OA) e ácido ursólico (UA) usados na medicina tradicional Chinesa (TCMs). Três triterpenos pentacíclicos ácidos foram separados em tampão ( $\mathrm{pH} 9,0)$ de metanol $6 \%$ (v/v), contendo $10 \mathrm{mmol} \mathrm{L}^{-1}$ de tetraborato dissódico, $10 \mathrm{mmol} \mathrm{L}^{-1}$ de hidrogênio fosfato de sódio, $50 \mathrm{mmol} \mathrm{L}^{-1}$ de dodecilsulfato de sódio, $15 \mathrm{mmol} \mathrm{L}^{-1}$ de 2-hidroxipropil- $\beta$-ciclodextrina em $15 \mathrm{~min}$. Uma boa relação linear entre a área de pico e a concentração foram obtidos nos intervalos de $16,5-330 \mu \mathrm{g} \mathrm{mL}^{-1}, 18-360 \mu \mathrm{g} \mathrm{mL} \mathrm{L}^{-1} \mathrm{e}$ 19,5-390 $\mu \mathrm{g} \mathrm{mL}^{-1}$ para BA, OA e UA, respectivamente. Comparado com cromatografia líquida de alta eficiência com $\gamma$-CD como fase móvel quiral aditiva (CMPA-HPLC), CD-MEKC apresentou melhor eficiência analítica para os três ácidos e o tempo analítico (15 min) foi mais curto do que para CMPA-HPLC (80 min).
\end{abstract}

A cyclodextrin-modified micellar electrokinetic chromatographic (CD-MEKC) method was developed to separate and determine betulinic acid (BA), oleanolic acid (OA) and ursolic acid (UA) in traditional Chinese medicines (TCMs). Three pentacyclic triterpene acids were baseline seperated in the buffer $(\mathrm{pH} 9.0)$ of $6 \%(\mathrm{v} / \mathrm{v})$ methanol containing $10 \mathrm{mmol} \mathrm{L}^{-1}$ disodium tetraborate, $10 \mathrm{mmol} \mathrm{L}^{-1}$ sodium dihydrogen phosphate, $50 \mathrm{mmol} \mathrm{L}^{-1}$ sodium dodecylsulfate, $15 \mathrm{mmol} \mathrm{L}^{-1}$ 2 -hydroxypropyl- $\beta$-cyclodextrin within $15 \mathrm{~min}$. The good linear relationships between the peak area and concentration were obtained in the ranges of $16.5-330 \mu \mathrm{g} \mathrm{mL}^{-1}, 18-360 \mu \mathrm{gL}^{-1}$ and 19.5-390 $\mu \mathrm{g} \mathrm{mL}^{-1}$ for BA, OA and UA, respectively. Compared with high performance liquid chromatography with $\gamma$-CD as chiral mobile phase additive (CMPA-HPLC), CD-MEKC has better analytical efficiency for three acids, and the analytical time (15 min) was shorter than that of CMPA-HPLC (80 $\mathrm{min})$.

Keywords: CD-MEKC, betulinic acid, oleanolic acid, ursolic acid, CMPA-HPLC

\section{Introduction}

Triterpenoids, such as betulinic acid (BA), oleanolic acid (OA) and ursolic acid (UA), existing in traditional Chinese medicines (TCMs) in the form of free acids or aglycones for triterpenoid saponins, ${ }^{1}$ possess important pharmacological properties. BA, a plant-derived pentacyclic lupane-type triterpene, has been shown to exert anti-inflammatory ${ }^{2}$ and anti-HIV activities. ${ }^{3} \mathrm{OA}$ and UA are position isomers (Figure 1). The only difference between them is the position of the methyl group on the ring E. They have been ascertained to have anti-diabetogenic, ${ }^{4}$ hepatoprotective,${ }^{5}$ antitumorigenesis ${ }^{6,7}$ and antioxidant effects. ${ }^{8}$

*e-mail: xqchen@mail.csu.edu.cn
The main analytical methods of triterpenoids in TCMs are gas chromatography (GC), ${ }^{9-11}$ high-performance liquid chromatography (HPLC), ${ }^{12}$ capillary zone electrophoresis $(\mathrm{CZE})^{13,14}$ and micellar electrokinetic chromatography (MEKC) ${ }^{15}$ However, the resolution of OA and UA was not satisfied by common HPLC or MEKC due to their similar molecular structures. Gas chromatography-mass spectrometry (GC-MS) via a time-consuming derivatisation reaction has already been used to identify $\mathrm{OA}$ and $\mathrm{UA},{ }^{16}$ and liquid chromatography-electrospray/atmospheric pressure chemical mass spectrometry (LC-ESI/APCI-MS) can be employed to identify $\mathrm{BA}^{17}$ and $\mathrm{UA},{ }^{18}$ as the triterpenoids have weak chromophores.

Cyclodextrins (CDs, $\alpha-, \beta-, \gamma-)$ are torus-shaped, enzymatically synthesized, non-reducing oligosaccharides 


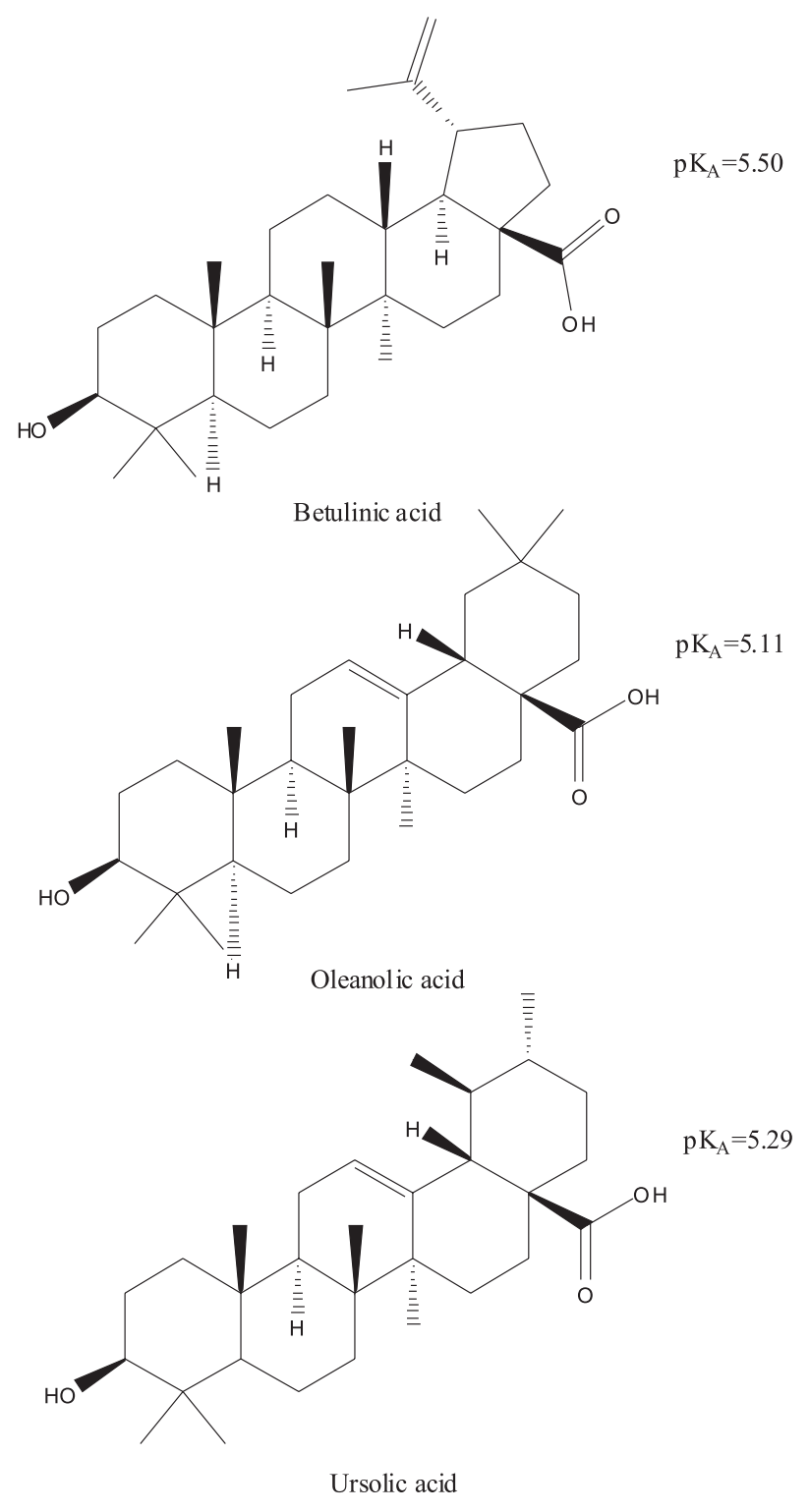

Figure 1. Chemical structures of the three pentacyclic triterpene acids.

consisting of $D$-glucopyranose units bonded through $\alpha-1,4-1$ inkages. The cavities of CDs are relatively hydrophobic while the external faces are hydrophilic. A cyclodextrin-modified MEKC (CD-MEKC) method ${ }^{19}$ and HPLC with CDs as chiral mobile phase additive (CMPAHPLC $)^{20}$ greatly expand the analytical applications. The hydrophobic cavities of CDs can form inclusion complexes with the analytes, which improves the separation of components with hydrophobic, isomerous or chiral properties significantly.

In this work, for the first time, a comparative study was carried out, in which a CD-MEKC method was validated for separation and determination of triterpene acids in samples and it was compared with CMPA-HPLC. And the factors affecting the separation of triterpenoids, including $\mathrm{pH}$ value, buffer concentration, organic modifier composition, SDS and CDs concentration in CD-MEKC were investigated.

\section{Experimental}

\section{Materials and reagents}

BA, OA and UA were provided by the National Institute for the Control of Pharmaceuticals and Biological Products (Beijing, China). Prunella vulgaris L., Diospyros kaki L. f., and Crataegus pinnatifida Bge., were purchased from Hubei, Shanxi and Hebei province of China, respectively. Sodium dodecylsulfate (SDS), sudan III and $\beta$-cyclodextrin ( $\beta$-CD) were obtained from Sinopharm Chemical Reagent Co., Ltd (Shanghai, China), 2 -hydroxypropyl- $\beta$ - cyclodextrin (HP- $\beta$-CD), 2,6-di- $O$ methyl- $\beta$-cyclodextrin (DM- $\beta-C D)$ and $\gamma$-cyclodextrin $(\gamma$-CD) from Sigma (St. Louis, MO, USA). Methanol was of LC grade (Hanbon Technologies, Jiangsu, China). All other reagents and solvents were of analytical reagent grade and used without further purification unless otherwise noted. All aqueous solutions were prepared using newly double-distilled water.

\section{Apparatus and conditions}

The CE analysis was carried out on a CL1030 capillary electrophoresis system (Beijing Cailu Scientific Inc., Beijing, China) equipped with a UV-Vis detector that can perform wavelength scanning from 190 to $740 \mathrm{~nm}$. An uncoated fused-silica capillary $(75 \mu \mathrm{m} \times 58 \mathrm{~cm}$, Ruipu Chromatogram Equipment Co., Ltd, Hebei, China) with an effective length of $50 \mathrm{~cm}$ was used to separate samples, which were injected into the capillary by hydrodynamic flow at a height differential of $10 \mathrm{~cm}$ for $10 \mathrm{~s}$. The applied voltage was $20 \mathrm{kV}$, and the detection wavelength was $210 \mathrm{~nm}$. At the beginning of experiment, the capillary was purged with $0.5 \mathrm{~mol} \mathrm{~L}^{-1} \mathrm{NaOH}$ for $5 \mathrm{~min}$, followed by $0.1 \mathrm{~mol} \mathrm{~L}^{-1} \mathrm{NaOH}$ for $5 \mathrm{~min}$, deionized water for $5 \mathrm{~min}$ and then running buffer for $5 \mathrm{~min}$. Between runs, the capillary was flushed with $0.1 \mathrm{~mol} \mathrm{~L}^{-1} \mathrm{NaOH}$ for 2 min followed by deionized water for $2 \mathrm{~min}$ and then running buffer $2 \mathrm{~min}$.

HPLC analysis was performed on a Shimadzu LC2010 apparatus equipped with a Shimadzu SPD-M10A photodiode array detector (Shimadzu Corporation, Kyoto, Japan). Separations were carried out at $30{ }^{\circ} \mathrm{C}$ on a Hedera ODS C ${ }_{18}$ column $(5 \mu \mathrm{m}, 250 \times 4.6 \mathrm{~mm}$, Hanbon Technologies, Jiangsu, China). The optimum wavelength for determination was $210 \mathrm{~nm}$. The flow rate of mobile

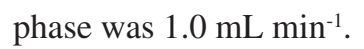




\section{Preparation of standard and sample solutions}

The stock solutions of BA, OA and UA were prepared by dissolving standards ( $6.6 \mathrm{mg}$ for BA, $7.2 \mathrm{mg}$ for OA and $7.8 \mathrm{mg}$ for UA, respectively) in $10 \mathrm{~mL}$ of methanol. Standard solutions of BA, OA and UA at various concentrations were prepared by diluting the stock solutions.

The pulverized samples (2.0 g for P. vulgaris, $4.6 \mathrm{~g}$ for Diospyros kaki L. f. and $1.0 \mathrm{~g}$ for C. pinnatifida, respectively) were extracted with petroleum ether $(50 \mathrm{~mL})$ at $60{ }^{\circ} \mathrm{C}$ for $10 \mathrm{~min}$ in an ultrasonic bath. After filtration, the residue was extracted with $95 \%$ ethanol $(50 \mathrm{~mL})$ for $20 \mathrm{~min}$ in an ultrasonic bath, and it was repeated twice. The extracts were combined, filtered and concentrated. Finally, the residue was dissolved with $10 \mathrm{~mL}$ of running buffer. The solution was then filtered through a $0.45 \mu \mathrm{m}$ membrane filter before injection.

\section{Results and Discussion}

\section{Method optimization}

\section{Mobility calculation}

The velocity of analytes can not be expressed by the migration time or apparent electrophoretic mobility in the separation systems. The effective electrophoretic mobility $\left(\mu_{\mathrm{ef}}\right)$ described by $\mathrm{Fu}^{22}$ as follows, avoiding the influence of electroosmotic flow, has been taken as the revised velocity of analytes. ${ }^{21}$

$\mu_{\mathrm{ef}}=\frac{\mathrm{k}}{\mathrm{k}+1} \mu_{\mathrm{ap}(\mathrm{mc})}$

where $\mathrm{k}$ is the column capacity factor, and $\mu_{\mathrm{ap}(\mathrm{mc})}$ is the apparent electrophoretic mobility of micella.

$$
\begin{aligned}
& \mathrm{k}=\frac{\mathrm{t}-\mathrm{t}_{0}}{\mathrm{t}_{0}\left(1-\mathrm{t} / \mathrm{t}_{\mathrm{mc}}\right)} \\
& \mu_{\mathrm{ap}(\mathrm{mc})}=\frac{\mathrm{L}_{\mathrm{ef}} \mathrm{L}_{\mathrm{t}}}{\mathrm{Vt}_{\mathrm{mc}}}
\end{aligned}
$$

where $\mathrm{t}, \mathrm{t}_{0}$ and $\mathrm{t}_{\mathrm{mc}}$ are the migration time of analyte, electroendosmotic flow marker (methanol in this experiment), and micella (sudan III used for marker) respectively. $\mathrm{L}_{\text {ef }}$ is the effective length of capillary between injection and detection, $\mathrm{L}_{\mathrm{t}}$ is the total length of capillary. $\mathrm{V}$ is the applied voltage.

Integration of these equations gives, the calculated equation of $\mu_{\text {eff }}$ was obtained as follows.

$$
\mu_{\text {ef }}=\frac{L_{e f} L_{t}}{V t} \cdot \frac{t-t_{0}}{t_{m c}-t_{0}}
$$

With high reliability of qualitative analysis, $\mu_{\text {eff }}$ was employed to identify the peaks of the triterpenoids in TCMs.

\section{Effect of SDS concentration on CE separation}

MEKC, a newly fast-developing CE mode, makes the separation of neutral compounds possible for applications. SDS, a typical anionic surfactant, was taken as micella in MEKC in this study, which affected the separation of triterpenoids at several concentration points checked (Figure 2). It can be seen that the effective mobilities difference between BA and OA was large, and the effective mobilities difference between OA and UA was almost zero when the SDS concentration approached to $10 \mathrm{mmol} \mathrm{L}^{-1}$. In addition, the effective electrophoretic mobilities and resolution of the triterpenoids increased as SDS concentration changed from 10 to $90 \mathrm{mmol} \mathrm{L}^{-1}$. However, the trend reduced gradually. Take the migration time of triterpenoids into consideration, a buffer solution with $50 \mathrm{mmol} \mathrm{L}^{-1} \mathrm{SDS}$ was selected.

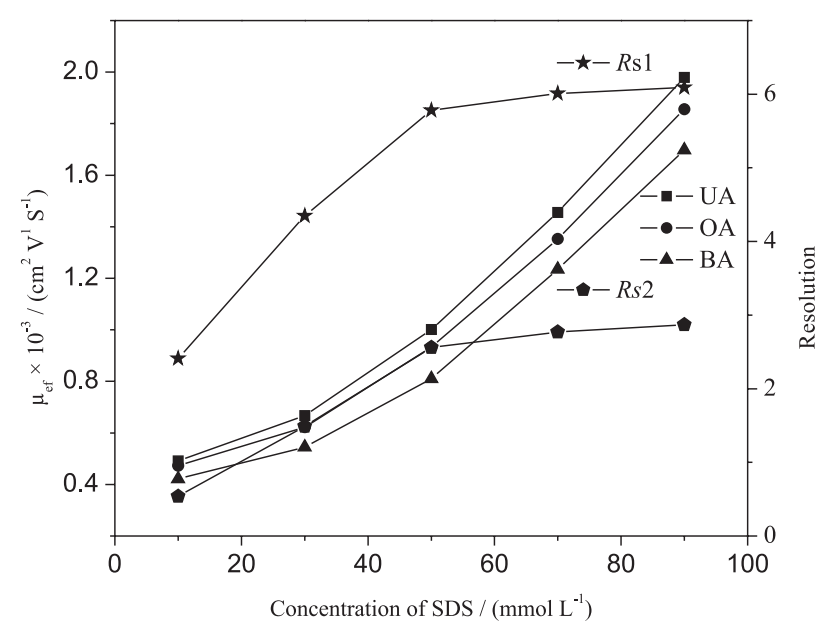

Figure 2. Effect of SDS concentration on CE separation. Conditions: $6 \%$ (v/v) methanol ( $\mathrm{pH} 9.0$ ) containing $10 \mathrm{mmol} \mathrm{L}^{-1}$ disodium tetraborate, $10 \mathrm{mmol} \mathrm{L}^{-1}$ sodium dihydrogen phosphate and $15 \mathrm{mmol} \mathrm{L}^{-1} \mathrm{HP}-\beta-\mathrm{CD}$; capillary, $58 \mathrm{~cm}(50 \mathrm{~cm}$ to detector $) \times 75 \mu \mathrm{m}$ i.d.; applied voltage, $20 \mathrm{kV}$; detection, $210 \mathrm{~nm}$. (Rs1, resolution of BA and OA; Rs2, resolution of OA and UA.).

Effect of borate-phosphate concentration on CE separation

The influence of borate-phosphate mixture on the separation of standard mixture of BA, OA and UA was investigated as listed in Table 1 . When buffer concentration exceeded $20 \mathrm{mmol} \mathrm{L}^{-1}$, the migration time of triterpenoids became longer obviously, because the value of zeta potential and EOF reduced as ionic strength increased. Meanwhile, the electric current and joule heat increased rapidly. Therefore, both sodium dihydrogen phosphate and disodium tetraborate concentrations were $10 \mathrm{mmol} \mathrm{L}^{-1}$ in the buffer. 
Table 1. Effect of buffer composition on the separation of triterpenoids

\begin{tabular}{lcc}
\hline No. & Buffer composition & Results \\
\hline 1 & $30 \mathrm{mmol} \mathrm{L}^{-1} \mathrm{~A}$ or B & Increasing migration time and poor resolution \\
2 & $20 \mathrm{mmol} \mathrm{L}^{-1} \mathrm{~A}$ or B & Shorter migration time, but poor peak shape \\
3 & $10 \mathrm{mmol} \mathrm{L}^{-1} \mathrm{~A}+10 \mathrm{mmol} \mathrm{L}^{-1} \mathrm{~B}$ & Appropriate migration time and better peak shape \\
\hline
\end{tabular}

A stands for disodium tetraborate; $\mathrm{B}$ stands for sodium dihydrogen phosphate.

\section{Effect of $\mathrm{pH}$ value on CE separation}

The $\mathrm{pH}$ value of running buffer may be a key factor affecting the peak shape and efficiency in CE system as the triterpenoids are all weak acids (pKa of the acids were given in Figure 1). In this experiment, the effect of $\mathrm{pH}$ value on the separation of triterpenoids studied from 6.0 to 10.0 was shown in Figure 3. As pH increased, the effective electrophoretic mobility of triterpenoids decreased and resulted in increased migration time. However, the resolution of triterpenoids was slightly improved; $\mathrm{pH} 9.0$ was finally selected.

\section{Effect of organic modifiers on CE separation}

Organic solvents can alter selectivity, reduce viscosity of background electrolyte, improve the resolution of the hydrophobic triterpenoids. Methanol, ethanol and acetonitrile at various concentrations were used in the running buffer for an attempt to improve the separation of the triterpenoids. However, as listed in Table 2, OA and UA can not be completely separated when ethanol or acetonitrile was used. Three sharp and symmetric peaks were achieved when a running buffer with $6 \%(\mathrm{v} / \mathrm{v})$ methanol was used. When the concentration of methanol exceeded $6 \%$, the resolution of the isomers changed very little.

\section{Effect of HP- $\beta$-CD concentration on CE separation}

The resolution of OA and UA by MEKC and the range of linearity were not satisfied. ${ }^{15}$ We have known that the triterpene acids can form inclusion complexes with CDs. The stability of the complexes has obviously effects on the resolution and the elution order of triterpenoids. ${ }^{23}$ Electrolyte systems containing HP- $\beta-\mathrm{CD}$ ranging from

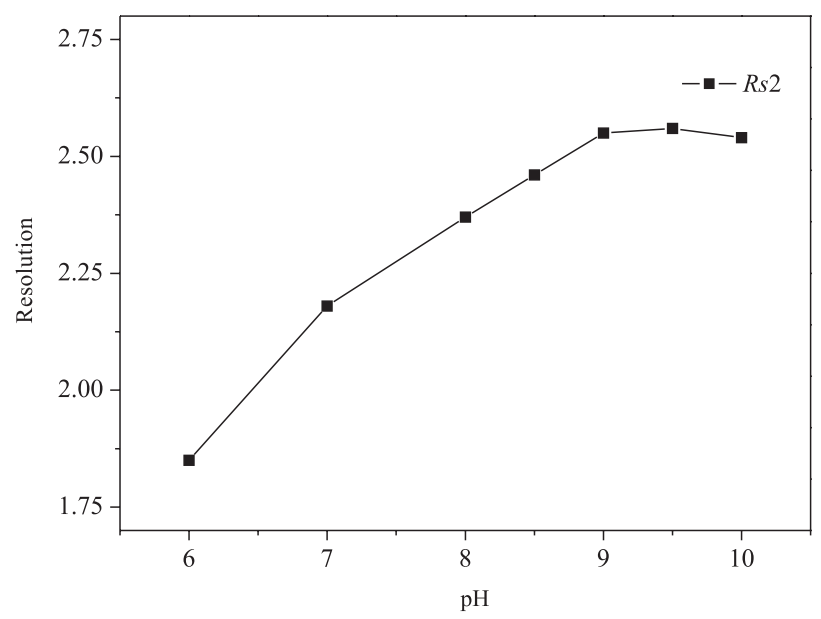

Figure 3. Effect of $\mathrm{pH}$ value on the resolution of the isomers. Conditions: $6 \%(\mathrm{v} / \mathrm{v})$ methanol containing $10 \mathrm{mmol} \mathrm{L}^{-1}$ disodium tetraborate, $10 \mathrm{mmol} \mathrm{L}^{-1}$ sodium dihydrogen phosphate, $50 \mathrm{mmol} \mathrm{L}^{-1} \mathrm{SDS}$ and $15 \mathrm{mmol} \mathrm{L}^{-1}$ HP- $\beta$-CD; capillary, $58 \mathrm{~cm}(50 \mathrm{~cm}$ to detector $) \times 75 \mu \mathrm{m}$ i.d.; applied voltage, $20 \mathrm{kV}$; detection, $210 \mathrm{~nm}$. (Rs2, resolution of OA and UA.).

5 to $25 \mathrm{mmol} \mathrm{L}^{-1}$ were tested. The results obtained were given in Figure 4. It was apparent that the resolution of triterpene acids changed dramatically with increasing HP- $\beta$-CD concentration. The resolution of OA and UA was found to be 2.56 when $15 \mathrm{mmol} \mathrm{L}^{-1} \mathrm{HP}-\beta-\mathrm{CD}$ was used in the buffer.

\section{Method validation}

\section{Linearity}

Three triterpenoids were separated in the buffer $(\mathrm{pH} 9.0)$ of $6 \%(\mathrm{v} / \mathrm{v})$ methanol containing $10 \mathrm{mmol} \mathrm{L}^{-1}$ disodium tetraborate, $10 \mathrm{mmol} \mathrm{L}^{-1}$ sodium dihydrogen

Table 2. Effect of organic modifiers composition on the separation of triterpenoids

\begin{tabular}{lcc}
\hline No. & organic modifiers composition & Results \\
\hline 1 & $5 \%(\mathrm{v} / \mathrm{v}) \mathrm{A}$ & Unstable baseline, and the peaks of OA and UA overlapped. \\
2 & $5 \%(\mathrm{v} / \mathrm{v}) \mathrm{B}$ & Relatively stable baseline, but two peaks still overlapped. \\
3 & $3 \%(\mathrm{v} / \mathrm{v}) \mathrm{C}$ & More stable baseline, and two acids separated from each other. \\
4 & $6 \%(\mathrm{v} / \mathrm{v}) \mathrm{C}$ & Relatively stable baseline and better resolution obtained. \\
5 & $9 \%(\mathrm{v} / \mathrm{v}) \mathrm{C}$ & Changed little. \\
\hline
\end{tabular}

A stands for acetonitrile; B stands for ethanol; C stands for methanol. 


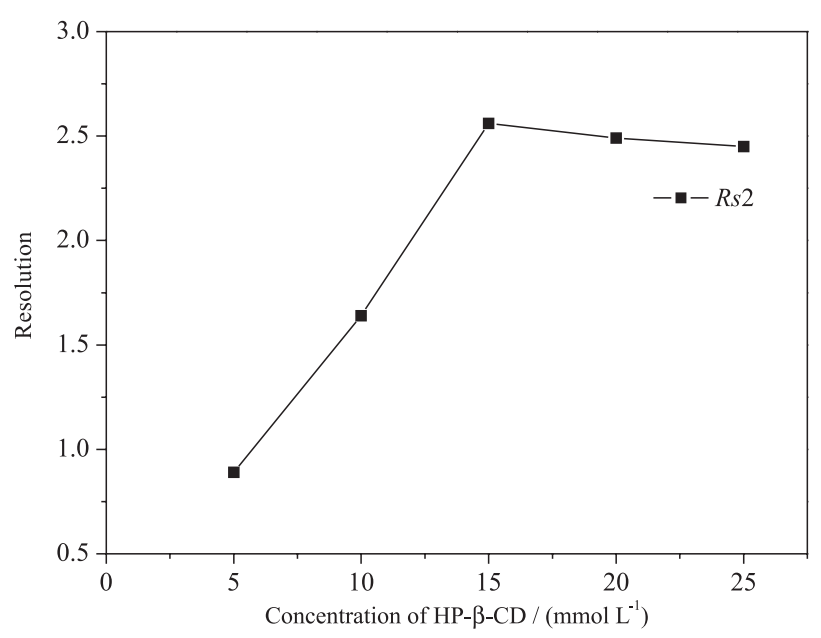

Figure 4. Effect of HP- $\beta$-CD concentration on the resolution of the isomers. Conditions: $6 \%(\mathrm{v} / \mathrm{v})$ methanol containing $10 \mathrm{mmol} \mathrm{L}^{-1}$ disodium tetraborate, $10 \mathrm{mmol} \mathrm{L}^{-1}$ sodium dihydrogen phosphate and $50 \mathrm{mmol} \mathrm{L}^{-1}$ SDS. Capillary, $58 \mathrm{~cm}(50 \mathrm{~cm}$ to detector $) \times 75 \mu \mathrm{m}$ i.d.; applied voltage, $20 \mathrm{kV}$; detection, $210 \mathrm{~nm}$. (Rs2, resolution of OA and UA.).

phosphate, $50 \mathrm{mmol} \mathrm{L}{ }^{-1} \mathrm{SDS}$ and $15 \mathrm{mmol} \mathrm{L} \mathrm{L}^{-1} \mathrm{HP}-\beta$ $\mathrm{CD}$ within $15 \mathrm{~min}$. The electropherogram of standard mixture was shown in Figure 5a. The peak area $(y / \mu \mathrm{V}$ s) and the concentration $\left(\mathrm{x} / \mu \mathrm{g} \mathrm{mL}^{-1}\right)$ were fit to the linear functions: $\mathrm{y}_{\mathrm{BA}}=2062+72.54 \mathrm{x}_{\mathrm{BA}}(\mathrm{r}=0.9985)$; $\mathrm{y}_{\mathrm{OA}}=1296+87.19 \mathrm{x}_{\mathrm{OA}}(\mathrm{r}=0.9989) ; \mathrm{y}_{\mathrm{UA}}=2870+83.98 \mathrm{x}_{\mathrm{UA}}$ $(\mathrm{r}=0.9988)$. And the good linear relationships between the peak area and concentration were obtained in the ranges of 16.5-330 $\mu \mathrm{g} \mathrm{mL}^{-1}, 18-360 \mu \mathrm{gL}^{-1}$ and $19.5-390 \mu \mathrm{gL}^{-1}$ for BA, OA and UA, respectively. The limits of detection (LOD) and limits of quantitation (LOQ) under the proposed CD-MEKC conditions were determined at a signal-to-noise ratio $(\mathrm{S} / \mathrm{N})$ of 3 and 10 , respectively. The values of $\mathrm{LOD}$ and LOQ were $2.1 \mu \mathrm{g} \mathrm{mL}^{-1}, 8.2 \mu \mathrm{g} \mathrm{mL}^{-1}$ for BA, $2.2 \mu \mathrm{g} \mathrm{mL} \mathrm{m}^{-1}$, $8.6 \mu \mathrm{g} \mathrm{mL} \mathrm{m}^{-1}$ for OA and $2.8 \mu \mathrm{g} \mathrm{mL}^{-1}, 10.3 \mu \mathrm{g} \mathrm{mL} \mathrm{L}^{-1}$ for UA, respectively.

\section{Precision}

The samples were prepared and determined by the method described above, the results of which were shown in Table 3, and the electropherogram of the sample B was shown in Figure $5 \mathrm{~b}$. The precision study was comprised of repeatability (intra-day precison) and reproducibility (interday precison) studies. The repeatability was established by analyzing each sample five times on the same day. The reproducibility was determined by analyzing each sample (one time/day) on a 5-day period. As listed in Table 3, we found that the relative standard deviation (R.S.D.) of intraday precision was less than $2.32 \%$ for $\mathrm{BA}, 2.31 \%$ for OA and $2.48 \%$ for UA, while the R.S.D. of inter-day precision was less than $3.12 \%$ for BA, $2.81 \%$ for OA and $3.31 \%$ for UA, respectively.
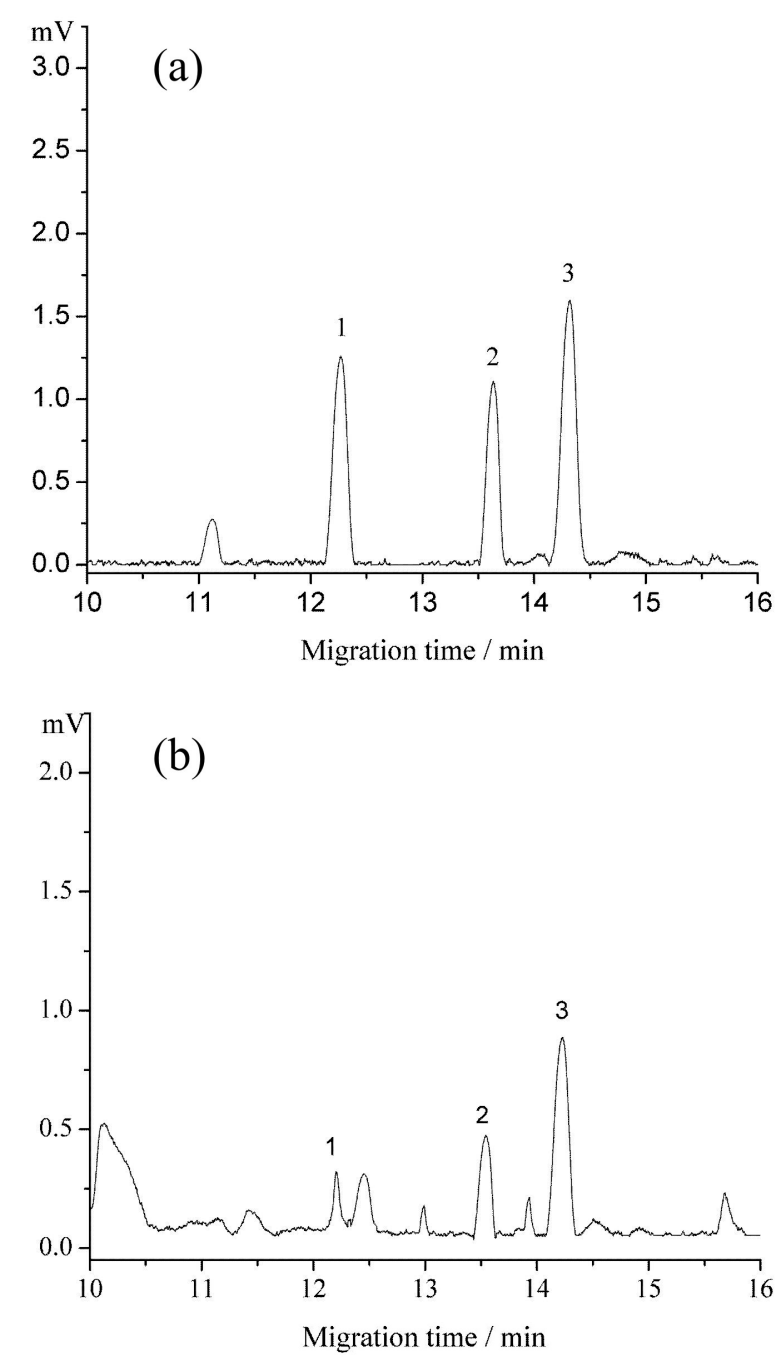

Figure 5. CD-MEKC electropherograms of standard mixure (a) and sample (B) (b) (1-BA; 2-OA; 3-UA). Buffer: 6\% (v/v) methanol containing $10 \mathrm{mmol} \mathrm{L}^{-1}$ disodium tetraborate, $10 \mathrm{mmol} \mathrm{L}^{-1}$ sodium dihydrogen phosphate, $50 \mathrm{mmol} \mathrm{L}^{-1}$ SDS and $15 \mathrm{mmol} \mathrm{L}^{-1} \mathrm{HP}-\beta-\mathrm{CD}$. capillary, $58 \mathrm{~cm}(50 \mathrm{~cm}$ to detector $) \times 75 \mu \mathrm{m}$ i.d.; applied voltage, $20 \mathrm{kV}$; detection, $210 \mathrm{~nm}$.

\section{Recovery and accuracy}

The recoveries of the triterpene acids were determined by the method of standards addition. Suitable amounts of three acids were spiked into sample B, which were determined previously. The mixture was extracted and analyzed by using the proposed procedure. Table 4 showed the recoveries of $\mathrm{BA}, \mathrm{OA}$ and $\mathrm{UA}$ applying a CDMEKC method. As listed in Table 4, the recoveries were 93.3-96.0\%, $95.2-102.9 \%$ and $93.8-103.1 \%$ for BA, OA and UA, respectively.

\section{Comparison of MEKC with $\gamma$-CD CMPA-HPLC}

OA and UA could not be well separated from each other by common HPLC on reversed column in my 
Table 3. Statistical results of precision of the triterpene acids $(n=5)$

\begin{tabular}{|c|c|c|c|c|c|}
\hline & & \multicolumn{2}{|c|}{ Intra-day Precision } & \multicolumn{2}{|c|}{ Inter-day Precision } \\
\hline & & Content / ( $\left.\mathrm{mg} \mathrm{g}^{-1}\right)$ & R.S.D / (\%) & Content / $\left(\mathrm{mg} \mathrm{g}^{-1}\right)$ & R.S.D / (\%) \\
\hline \multirow[t]{3}{*}{ A } & $\mathrm{BA}$ & \multicolumn{2}{|c|}{$\#$} & \multicolumn{2}{|c|}{$\#$} \\
\hline & $\mathrm{OA}$ & 1.11 & 2.11 & 1.16 & 2.81 \\
\hline & UA & 2.44 & 2.21 & 2.46 & 2.96 \\
\hline \multirow[t]{3}{*}{ B } & $\mathrm{BA}$ & 0.29 & 2.32 & 0.31 & 3.12 \\
\hline & $\mathrm{OA}$ & 0.48 & 2.19 & 0.48 & 2.77 \\
\hline & UA & 1.58 & 2.25 & 1.61 & 3.15 \\
\hline \multirow[t]{3}{*}{$\mathrm{C}$} & $\mathrm{BA}$ & \multicolumn{2}{|c|}{$\#$} & \multicolumn{2}{|c|}{$\#$} \\
\hline & $\mathrm{OA}$ & 1.23 & 2.31 & 1.25 & 2.72 \\
\hline & UA & 4.22 & 2.48 & 4.25 & 3.31 \\
\hline
\end{tabular}

\# not detected. A stands for P. vulgaris; B stands for leaves of Diospyros kaki L.f.; C stands for C. pinnatifida.

Table 4. Recoveries of BA, OA and UA in sample B applying a CD-MEKC method

\begin{tabular}{lcccc}
\hline Components & Cotent $/\left(\mathrm{mg} \mathrm{g}^{-1}\right)$ & Added / $\left(\mathrm{mg} \mathrm{g}^{-1}\right)$ & Found $/\left(\mathrm{mg} \mathrm{g}^{-1}\right)$ & Recovery / $\%)$ \\
\hline BA & 0.29 & $0.15,0.21,0.25$ & $0.43,0.49,0.53$ & $93.3,95.2,96.0$ \\
OA & 0.48 & $0.21,0.28,0.35$ & $0.68,0.75,0.84$ & $95.2,96.4,102.9$ \\
UA & 1.58 & $0.32,0.52,0.96$ & $1.88,2.09,2.57$ & $93.8,98.1,103.1$ \\
\hline
\end{tabular}

previous experiments. The resolution of the triterpenoids can be improved by CDs added to the HPLC mobile phase. Different concentrations of $\beta-C D, H P-\beta-C D, D M-\beta-C D$ and $\gamma-\mathrm{CD}$, used as the chiral additives, were added to the mobile phase to investigate the effect of CDs on the separation of the triterpene acids. However, OA and UA could still not be completely separated when $\beta-C D, H P-\beta-$ CD and DM- $\beta-C D$ were used. When $5.0 \mathrm{mmol} \mathrm{L}^{-1} \gamma-\mathrm{CD}$ was added to methanol/ $\mathrm{H}_{2} \mathrm{O}, \mathrm{pH} 6.0,(75 / 25$, v/v), the two acids were well resolved (Figure 6). $\gamma$-CD, with larger cavity and

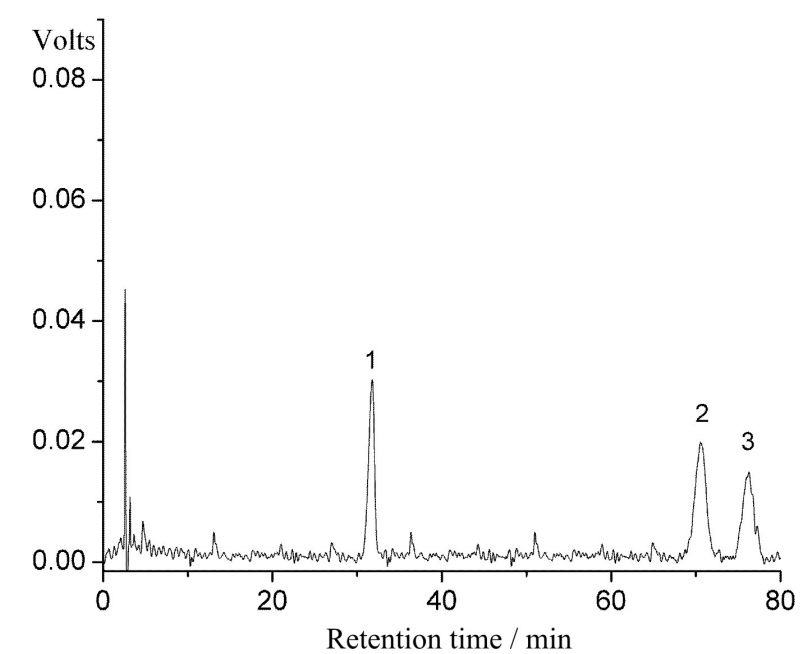

Figure 6. CMPA-HPLC chromatogram of standard mixure (1-BA; 2-UA; 3-OA). Column: Hedera ODS C $18: 250 \mathrm{~mm} \times 4.6 \mathrm{~mm}$ i.d.(5 $\mu \mathrm{m})$; flow-rate: $1 \mathrm{~mL} \mathrm{~min}{ }^{-1}$; injection volume: $10 \mu \mathrm{L}$; detection, $210 \mathrm{~nm}$; mobile phase: methanol/ $\mathrm{H}_{2} \mathrm{O}, \mathrm{pH} 6.0,(75 / 25, \mathrm{v} / \mathrm{v})+5 \mathrm{mmol} \mathrm{L}^{-1} \gamma-\mathrm{CD}$. better water-solubility than other CDs, can form stable and hydrophilic inclusion complexes with the triterpenoids. Chromatographic properties of the triterpenoids, once included, may be dramatically affected. Furthermore, the elution order of OA and UA changed because it depends on the nature of the CDs. ${ }^{23}$ As a result, the more stable $\gamma$-CD complexes are formed with UA compared to OA when $5.0 \mathrm{mmol} \mathrm{L}^{-1} \gamma$-CD was selected.

The CMPA-HPLC method appeared to cost time and suffer from complexity, whereas the CD-MEKC method described here was simple, robust and cost-effective while retaining sufficient analytical efficiency (Table 5). It took more than $75 \mathrm{~min}$ for a CMPA-HPLC analysis, but only $15 \mathrm{~min}$ for CD-MEKC analysis.

Table 5. Number of theoretical plates $\left(\times 10^{4}\right)$ for triterpenoids analyzed with CMPA-HPLC and CD-MEKC

\begin{tabular}{lccc}
\hline Method & BA & OA & UA \\
\hline CMPA-HPLC & 1.28 & 1.35 & 1.22 \\
CD-MEKC & 6.67 & 7.19 & 5.81 \\
\hline
\end{tabular}

\section{Conclusions}

In this paper, a baseline separation of triterpenoids in TCMs was achieved by using MEKC with HP- $\beta-C D$ as chiral selector. Three pentacyclic triterpene acids were baseline seperated in the buffer $(\mathrm{pH} 9.0)$ of $6 \%(\mathrm{v} / \mathrm{v})$ 
methanol containing $10 \mathrm{mmol} \mathrm{L}^{-1}$ disodium tetraborate, $10 \mathrm{mmol} \mathrm{L}^{-1}$ sodium dihydrogen phosphate, $50 \mathrm{mmol} \mathrm{L}^{-1}$ SDS, $15 \mathrm{mmol} \mathrm{L}^{-1} \mathrm{HP}-\beta-\mathrm{CD}$ within $15 \mathrm{~min}$. A pathbreaking study was carried out comparatively. Compared with CMPA-HPLC, CD-MEKC has the advantages of rapidity, accuracy and high efficiency. It can be used for quantitative study and quality control of TCMs.

\section{References}

1. Liu, J.; J. Ethnopharmacol. 1995, 49, 57.

2. Mukherjee, P. K.; Saha, K.; Das, J.; Pal, M.; Saha, B. P.; Planta Med. 1997, 63, 367.

3. Fujioka, T.; Kashiwada, Y.; Kilkuskie, R. E.; Cosentino, L. M.; Ballas, L. M.; Jiang, J. B.; Janzen, W. P.; Chen, I. S.; Lee, K. H.; J. Nat. Prod. 1994, 57, 243.

4. Yoshikawa, M.; Matsuda, H.; Biofactors 2000, 13, 231.

5. Jeong, H. G..; Toxicol. Lett. 1999, 105, 215.

6. Huang, M. T.; Ho, C. T.; Wang, Z. Y.; Ferraro, V.; Lou, Y. R.; Stauber, K.; Ma, W.; Georgiadis, C.; Laskin, J. D.; Cancer Res. 1994, 54, 701.

7. Ohigashi, H.; Takamura, H.; Koshimizu, K.; Tokuda, H.; Ito, Y.; Cancer Lett. 1986, 30, 143.

8. Balanehru, S.; Nagarajan, B.; Biochem. Int. 1991, 24, 981.

9. Janicsak, G.; Veres, K.; Kallai, M.; Mathe, I.; Chromatographia 2003, 58, 295.

10. Takeoka, G.; Dao, L.; Teranishi, R.; Wong, R.; Flessa, S.; Harden, L.; Edwards, R.; J. Agric. Food Chem. 2000, 48, 3437.
11. Perez-Camino, M. C.; Cert, A.; J. Agric. Food Chem. 1999, 47, 1558.

12. Chen, J. H.; Xia, Z. H.; Tan, R. X.; J. Pharm. Biomed. Anal. 2003, 32, 1175.

13. Guo, Q. L.; Gao, J. Y.; Yang, J. S.; Chromatographia 2005, 62, 145.

14. Yang, P.; Li, Y. Q.; Liu, X.; Jiang, S. X.; J. Pharm. Biomed. Anal. 2007, 43, 1331.

15. Liu, H. X.; Shi, Y. H.; Wang, D. X.; Yang, G. L.; Yu, A. M.; Zhang, H. Q.; J. Pharm. Biomed. Anal. 2003, 32, 479.

16. Colombini, M. P.; Modugno, F.; Giannarelli, S.; Fuoco, R.; Matteini, M.; Microchem. J. 2003, 67, 385.

17. Shin, Y. G.; Cho, K. H.; Chung, S. M.; Graham, J.; Das Gupta, T. K.; Pezzuto, J. M.; J. Chromatogr., B 1999, 732, 331.

18. Novotny, L.; Abdel-Hamid, M. E.; Hamza, H.; Masterova, I.; Grancai, D.; J. Pharm. Biomed. Anal. 2003, 31, 961.

19. Zhang, G. Q.; Qi, Y. P.; Lou, Z. Y.; Liu, C. H.; Wu, X. F.; Chai, Y. F.; Biomed. Chromatogr. 2005, 19, 529.

20. Li, F. M.; Zhang, D. D.; Lu, X. M.; Wang, Y. L.; Xiong, Z. L.; Biomed. Chromatogr. 2004, 18, 866.

21. Zhen, Y. F.; Liu, D. Y.; Xiong, J. H.; Zhang, P. D.; Zhan, Z.; Xu, G. W.; Chin. J. Anal. Chem. 2002, 30, 645.

22. Fu, R. N.; Outline of Chromatographic Analysis, $2^{\text {nd }}$ ed., Chemical Industry Press: Beijing, 2005.

23. Claude, B.; Morin, P.; Lafosse, M.; Andre, P.; J. Chromatogr., A 2004, 1049, 37.

Received: October 28, 2007 Web Release Date: May 29, 2009 